\title{
PENINGKATAN MINAT DAN HASIL BELAJAR PENDIDIKAN AGAMA KRISTEN (PAK) MELALUI PENERAPAN MODEL PEMBELAJARAN BERMAIN PERAN
}

\author{
Jefry Kurniawan Korua ${ }^{1}$, Sahat Siagia ${ }^{2}$, Abdul Hamid K. ${ }^{3}$ \\ ${ }^{1}$ Sekolah Menengah Pertama Bethany Medan, Sumatera Utara \\ ${ }^{2,3}$ Program Pascasarjana, Universitas Negeri Medan, Medan \\ ljefrykurniawan@gmail.com; ${ }^{2}$ sahat.sgn61@gmail.com, ${ }^{3}$ abdhamid_k@yahoo.com
}

\begin{abstract}
Abstrak: Tujuan Penelitian Tindakan Kelas ini adalah untuk meningkatkan minat siswa dalam mengikuti proses pembelajaran Pendidikan Agama Kristen dan hasil belajar melalui penerapan model pembelajaran Role Play. Penelitian ini dilaksanakan kepada semua siswa kelas IX yang berjumlah tujuh laki-laki dan delapan perempuan. Data dianalisis dengan mempergunakan teknik : (1) reduksi data, (2) sajian deskriptif, dan (3) verifikasi atau penarikan kesimpulan berdasarkan Kriteria Ketuntasan Minimal sesuai dengan penilaian yang berlaku dalam Kurikulum Tingkat Satuan Pendidikan SMP Bethany Medan. Kondisi awal kemampuan siswa sebelum pelaksanaan tindakan adalah $40 \%$, dan hasil analisis menunjukkan bahwa penerapan model pembelajaran Role Play dapat meningkatkan minat belajar yang sejalan dengan peningkatan hasil belajar siswa yang signifikan yaitu 53\% pada Siklus I menjadi 80\% pada Siklus II. Hasil PTK ini diharapkan dapat menjadi masukan yang berharga bagi para guru PAK untuk dapat memilih dan mengembangkan model pembelajaran yang sesuai dengan karakteristik siswa dan materi yang dipelajari secara efisien, efektif, berdaya tarik, dan humanis mengingat fungsi, tujuan, dan ruang lingkup PAK yang strategis dalam mendorong terjadinya transformasi dalam kehidupan siswa yang berakhlak mulia, beriman, dan bertaqwa kepada Tuhan Yang Maha Esa.
\end{abstract}

Kata Kunci: pendidikan agama kristen (pak), model pembelajaran bermain peran

\begin{abstract}
The objectives of this Classroom Action Research were to improve students' interest in attending the instructional process of Christian Education through the application of Role Play and learning achievement through Role Play model. The reasearch was conducted to all Grade IX students comprising of seven boys and eight girls. The instruments used were : (1) observation sheet, (2) questionnaire, and (3) learning performance evaluation. The data were analysed using the technique of: (1) data reduction, (2) descriptive presentation, and (3) verification or drawing conclusion based on the Minimal Mastery Criteria with the score of 75 in line with the scoring system applied in the Educational Unit Level Curriculum of Bethany Junior High School Medan. The initial condition of the students' achievement before the conduction of the treatment was $40 \%$, and the results of the analyses show that Role Play model can improve students' interest which is in line with the significant improvement in learning achievement i.e. from 53\% in Cycle I to $80 \%$ in Cycle II. The CAR findings is expected to give a valuable input to Christian Education teachers in choosing and developing the instructional model based on the students' characterictics and the learning materials should be efficient, effective, interesting, and hamunism by consedering the function, objective, and scope of Christian Education which is very strategic in supporting the transformation at the students environment with noble character, faith, and devotion to God The Almighty.
\end{abstract}

Keywords: christian religious education (pak), role playing learning model

\section{PENDAHULUAN}

Pendidikan Agama Kristen (PAK) merupakan salah satu dari beberapa pendidikan agama yang ditetapkan oleh pemerintah sebagai mata pelajaran wajib yang diberikan dari jenjang paling dasar yakni usia dini sampai jenjang pendidikan tinggi. Dalam Peraturan Pemerintah No. 55 Tahun 2007 tentang Pendidikan Agama dan Pendidikan Keagamaan Bab III Pasal 8 pendidikan keagamaan berfungsi mempersiapkan peserta didik menjadi anggota masyarakat yang memahami dan 
mengamalkan nilai-nilai ajaran agamanya dan atau menjadi ahli ilmu agamanya.

Berdasarkan Standar Isi yang dikembangkan oleh Badan Standar Nasional Pendidikan (BSNP), Penerapan Standar Kompetensi (SK) dan Kompetensi Dasar (KD) di bidang PAK bertujuan mencapai untuk mencapai transformasi nilai-nilai kristiani dalam kehidupan peserta didik pada jenjang pendidikan dasar dan menengah. SK dan KD memberikan ruang yang sama kepada setiap peserta didik dan keunikan yang berbeda untuk mengembangkan pemahaman, tingkat kemampuan serta daya kreativitas masingmasing. Selanjutnya SK dan KD bukanlah "standar moral" Kristen yang ditetapkan untuk mengikat peserta didik, melainkan dampingan dan bimbingan bagi peserta didik dalam melakukan perjumpaan dengan Tuhan Allah untuk mengekspresikan hasil perjumpaan itu dalam kehidupan sehari-hari. Peserta didik memahami, mengenal dan bergaul dengan Tuhan Allah secara akrab dalam kehidupan sehari-hari.

Berdasarkan pemahaman tersebut, maka rumusan Standar Kompetensi dan Kompetensi Dasar PAK di sekolah dibatasi hanya pada aspek yang secara substansial mampu mendorong terjadinya transformasi dalam kehidupan peserta didik terutama dalam pengayaan nilai-nilai iman kristiani. Dogma yang lebih spesifik dan mendalam diajarkan di dalam gereja. Transformasi kehidupan adalah kata kunci dari tujuan pembelajaran PAK di sekolah. PAK harus mampu mewujudkan peserta didik yang berkarakter dan berperilaku baik dalam kehidupan sehari-hari sesuai dengan nilai-nilai kekristenan.

Namun kenyataan yang ada menunjukkan pembelajaran PAK khususnya di tingkat Sekolah Menengah Pertama masih didominasi dengan pola klasik guru mata pelajaran PAK yang mengajarkan agama hanya sebatas rutinitas. Sementara itu peserta didik hanya mengejar nilai dan bersama guru melupakan aplikasinya. Dengan alokasi jam pelajaran yang terbatas (2 jam pelajaran/minggu), PAK terkesan hanya mata pelajaran formalitas sementara Undang-Undang mengamanatkan fungsi dan perannya yang strategis. Kondisi inilah yang dijumpai di SMP Swasta Bethany Simalingkar, Medan. Sekolah Bethany merupakan sekolah swasta yang meletakkan ajaran kekristenan sebagai dasar dalam pelaksanaan pendidikan di sekolah sehingga mayoritas peserta didiknya beragama Kristen.

Walaupun sebagai sekolah yang meletakkan ajaran kristen sebagai dasar dalam proses pendidikannya, pembelajaran PAK di sekolah ini cenderung masih menjadi school knowledge ketimbang menjadi action knowledge. School knowledge dan Action knowledge merupakan sebuah konsep belajar yang telah lama diperkenalkan oleh Douglas Barnes sejak tahun 1975. Deskripsi perbedaan school knowledge dan action knowledge (Barnes, 1977) adalah sebagai berikut :

\footnotetext{
Perbedaan School Knowledge dan Action Knowledge School Knowledge

- Pengetahuan yang diperoleh di sekolah biasanya hanya diterapkan dan digunakan di sekolah

- Pengetahuan disajikan jadi bagi peserta didik.

- Peserta didik cukup untuk menjawab pertanyaan guru, mengerjakan latihan, dan mengerjakan ujian. Ilmu hanya sekedar diingat dan untuk ujian sekolah dan disesuaikan dengan keinginan guru.

- Peserta didik tidak memiliki ruang untuk menggambar dan mengarang sesuai dengan imajinasinya.

- Guru mengontrol materi pelajaran.

- Seolah-olah peserta didik hanya mengumpulkan saja ilmu-ilmu tersebut.

- Jika jarang digunakan kemungkinan pengetahuan atau ilmu tersebut dapat dilupakan.

Action knowledge

- Pengetahuan yang didapat bisa direalisasikan di kehidupan nyata.

- Tidak perlu "learning by doing" sebab learning by doing adalah menjadi salah satu bagian dari action knowledge.

- Ilmu itu tidak hanya diajarkan kepada peserta didik dengan ceramah, tetapi bagaimana ilmu dibangun dalam pikiran peserta didik melalui sebuah explorasi (penjelajahan). Manusia itu bisa menangkap ilmu karena punya pikiran, dan di dalam pikiran itu ada kecerdasan.

- Yang diharapkan dari peserta didik adalah berpikir original dari pengalaman kehidupannya, dengan demikian, setiap peserta didik memiliki pengetahuan yang berbeda.

- Belajar harus di kontekstualkan dengan masalah lingkungan, sehingga ilmu itu dapat diterapkan dalam kehidupan.
} 
Dalam pelaksanan pembelajaran di kelas VIII yang dilakukan selama ini, pembelajaran masih dilakukan dengan metode ekspositori atau ceramah. PAK disajikan dalam kerangka school knowledge. School knowledge adalah bentuk belajar formal. Bentuk belajar formal adalah kegiatan belajar yang bersifat sangat terstruktur, berbasis belajar di kelas, dan dirancang secara sistematis oleh sekolah. Umumnya guru sangat mengontrol dan terpusat pada materi pelajaran yang sudah disiapkan sebelumnya dimana peserta didik mengikuti kegiatan belajar secara terstruktur sesuai dengan kemauan guru. Materi pelajaran bersifat teoretis, abstrak dan berbasis text book. Masalah pembelajaran yang monoton tersebut berdampak pada hasil belajar PAK yang belum sesuai dengan harapan. Nilai murni hasil tes formatif dan sumatif peserta didik banyak yang belum mencapai nilai Kriteria Ketuntasan Minimal (KKM) 75 yang ditetapkan sekolah khususnya untuk nilai formatif dalam bentuk tes uraian/esai. Data menunjukkan mayoritas peserta didik mengalami kesulitan dalam mengerjakan atau menyelesaikan tes hasil belajar dalam bentuk tes uraian/esai. Hal tersebut menunjukkan bahwa kemampuan peserta didik masih rendah dalam menuliskan, menuangkan, dan menghubungkan apa yang telah mereka pelajari dengan kenyataan seharihari. Mayoritas kemampuan peserta didik masih terbatas dalam menentukan pilihan jawaban dari alternatif jawaban yang diberikan dalam soal pilihan ganda (objective tes).

Hasil kajian secara dialogis partisipatif ditemukan faktor-faktor penyebab belum maksimalnya hasil belajar PAK tersebut yang dibedakan ke dalam faktor internal dan eksternal. Faktor internal terkait dengan kondisi peserta didik seperti sikap, kondisi psikologis, dan minat belajar peserta didik yang kurang mendukung. Faktor eksternal berkaitan dengan kondisi atau keadaan di luar peserta didik seperti lingkungan, model pembelajaran, peran guru, dan media yang ada. Faktor internal dan eksternal tersebut merupakan faktor yang saling berhubungan, seperti rendahnya minat belajar disebabkan karena kondisi pembelajaran yang monoton sehingga membosankan bagi peserta didik.

\section{Hakikat Belajar dan Hasil Belajar PAK}

Menurut teori belajar behaviorisme, belajar adalah perubahan tingkah laku. Seseorang dianggap telah belajar sesuatu bila telah mampu menunjukkan perubahan tingkah laku. Manusia sangat dipengaruhi oleh kejadian-kejadian dalam lingkungan yang akan memberikan pengalaman. Belajar di sini merupakan perubahan tingkah laku yang terjadi berdasarkan paradigma Stimulus - Respon ( $\mathrm{S}$ $\mathrm{R})$, yaitu proses memberikan respon tertentu kepada stimulus yang datang dari luar.

Thorndike dalam teorinya yang disebut "Connectionisme" menyatakan bahwa belajar proses pembentukan koneksi-koneksi antara stimulus dan respon. Teori ini sering pula disebut "trial and error learning" individu yang belajar melakukan kegiatan melalui proses "trial and error" dalam rangka memilih respon yang tepat bagi stimulus tertentu.

Menurut Cronbach (1945) belajar adalah usaha aktifitas yang ditunjukan oleh perubahan tingkah laku sebagai hasil dari pengalaman. Crow and Crow (1985) mendefinisikan belajar adalah diperolehnya kebiasaan-kebiasaan, pengetahuan dan sikap baru. Tentu saja perubahan yang didapatkan itu bukan perubahan fisik, tetapi perubahan jiwa dengan sebab masuknya kesan-kesan yang baru. Perubahan sebagai hasil dari proses belajar adalah perubahan yang mempengaruhi tingkah laku seseorang

Prinsip-prinsip teori behaviorisme yang diterapkan dalam proses pembelajaran yaitu : (1) proses belajar dapat terjadi dengan baik apabila pebelajar ikut berpartisipasi secara aktif di dalamnya, (2) materi pelajaran dibentuk dalam bentuk unit-unit kecil dan diatur berdasarkan urutan yang logis sehingga pebelajar mudah mempelajarinya, antara lain juga di sini mereka hanya perlu memberikan respon tertentu saja, (3) tiap-tiap respon perlu diberi umpan balik secara langsung sehingga pebelajar dapat segera mengetahui apakah respon yang diberikan telah benar atau belum, (4) setiap kali pebelajar memberikan respon yang benar, maka perlu diberikan penguatan. Penguatan yang positif ternyata memberikan pengaruh yang lebih baik dari pada penguatan negatif (Hartley and Davies, 1978).

Selanjutnya berkaitan dengan hasil belajar, menurut Gagné (1985), belajar telah terjadi apabila pebelajar telah memperoleh kapabilas tertentu untuk melakukan sesuatu. Untuk keperluan merancang pembelajaran, Gagné mengemukakan 5 kategori kapabilitas yang dipelajari oleh pebelajar, yaitu :

1. Informasi verbal; yaitu penguasaan informasi dalam bentuk verbal, baik secara 
tertulis maupun lisan, misalnya pemberian nama-nama terhadap suatu benda, definisi, dan sebagainya.

2. Kecakapan intelektual; yaitu keterampilan individu dalam melakukan interaksi dengan lingkungannya dengan menggunakan simbol-simbol, misalnya: penggunaan simbol matematika. Termasuk dalam keterampilan intelektual adalah kecakapan dalam membedakan (discrimination), memahami konsep konkrit, konsep abstrak, aturan dan hukum. Ketrampilan ini sangat dibutuhkan dalam menghadapi pemecahan masalah.

3. Strategi kognitif; kecakapan individu untuk melakukan pengendalian dan pengelolaan keseluruhan aktivitasnya. Dalam konteks proses pembelajaran, strategi kognitif yaitu kemampuan mengendalikan ingatan dan cara - cara berpikir agar terjadi aktivitas yang efektif. Kecakapan intelektual menitikberatkan pada hasil pembelajaran, sedangkan strategi kognitif lebih menekankan pada pada proses pemikiran.

4. Sikap, yaitu hasil pembelajaran yang berupa kecakapan individu untuk memilih macam tindakan yang akan dilakukan. Dengan kata lain. Sikap adalah keadaan dalam diri individu yang akan memberikan kecenderungan bertindak dalam menghadapi suatu obyek atau peristiwa, didalamnya terdapat unsur pemikiran, perasaan yang menyertai pemikiran dan kesiapan untuk bertindak.

5. Kecakapan motorik; ialah hasil belajar yang berupa kecakapan pergerakan yang dikontrol oleh otot dan fisik.

\section{Hakikat Minat Belajar}

Kata minat dalam bahasa Inggris disebut interest yang dapat diartikan perhatian, ketertarikan, atau menarik. Beberapa ahli pendidikan memberikan definisi minat berkaitan dengan proses belajar. Menurut Crow dan Crow (1985), minat adalah "sebagai kekuatan pendorong yang menyebabkan individu memberikan perhatian kepada seseorang, sesuatu atau kepada aktifitas tertentu". Menurut Bimo Walgito menyatakan bahwa minat yaitu "suatu keadaan dimana seseorang mempunyai perhatian terhadap sesuatu dan disertai dengan keinginan untuk mengetahui dan mempelajari maupun membutuhkan lebih lanjut". Higlard (2003) menyatakan minat adalah kecenderungan untuk tetap memperhatikan dan menikmati beberapa kegiatan. Slameto sendiri mendefinisikan sebagai rasa suka dan rasa ketertarikan pada suatu hal atau sesuatu tanpa ada yang menyuruh (Slameto, 2003).

Sementara itu minat belajar menurut Lester D. Crow, Alice D. Crow adalah kemampuan untuk memberikan stimulus yang mendorong untuk memperhatikan seseorang, suatu barang atau kegiatan (Crow and Crow, 1985). Sedangkan menurut Winkel (1984) menyatakan bahwa minat merupakan kecondongan merasa terbaik pada bidang tertentu dan merasa senang berkecimpung dalam bidang-bidang itu.

Minat sangat berpengaruh pada tugas peserta didik. Jika seseorang pesert didik menaruh minat pada sebuah tugas maka ia akan melaksanakan tugas dengan baik, sekalipun menyita waktu sehingga tanpa disadari ia bekerja melebihi batas waktu maupun kesehatannya. Dengan kata lain, minat erat hubungannya dengan rasa suka atau tidak suka seseorang terhadap sesuatu tindakan.

Hurlock (1993) membagi minat dalam dua aspek, yaitu aspek kognitif dan aspek afektif. Dalam aspek ini nantinya akan diketahui indikator peningkatan minat peserta didik dalam suatu mata pelajaran. Adapun Aspek tersebut akan dijelaskan sebagai berikut: a. Aspek kognitif

Aspek kognitif minat berdasarkan atas konsep yang dikembangkan anak mengenai bidang yang terkait dengan minat, misalnya aspek kognitif dari minat anak terhadap mata pelajaran tertentu. Seorang peserta didik akan menganggap kelas adalah tempat yang menyenangkan untuk belajar, jika mereka dapat menemukan suasana yang tidak membosankan, misalnya dengan menemukan hal-hal yang baru, baik strategi pembelajaran maupun wawasan yang dipelajari, sehingga menimbulkan rasa ingin tahu yang terus menerus. Untuk mengetahui minat seorang peserta didik terhadap sesuatu yang disukai maka seorang peserta didik akan terus mencari tahu sesuatu yang terkait dengan minatnya.

\section{Kebutuhan akan informasi}

Peserta didik akan berminat terhadap pelajaran, jika dalam diri peserta didik merasa butuh terhadap karena peserta didik secara sadar beranggapan bahwa sebuah materi bermanfaat dan penting bagi kehidupan sehari-hari. Sehingga untuk memenuhi kebutuhan tersebut peserta didik 
akan memperhatikan hal-hal yang disampaikan oleh pengajar. Maka peserta didik akan berusaha menggali sebanyak mungkin informasi yang berkaitan dengan apa yang disukainya.

\section{Rasa ingin tahu}

Besarnya rasa ingin tahu peserta didik terhadap mata pelajaran dapat menentukan tingkat keterkaitan seseorang terhadap mata pelajaran tersebut, seorang peserta didik yang merasa ingin tahu lebih dalam tentang aqidah dan akhlak, maka peserta didik selalu memperhatikan dan aktif dalam kelas. Semakin besar tingkat keingintahuan seseorang maka semakin banyak hal-hal yang dicari dalam memenuhi kebutuhannya.

b. Aspek afektif

Aspek afektif minat berkembang dari pengalaman pribadi yang berasal dari lingkungan keluarga maupun sekolah. Lingkungan belajar akan lebih berpengaruh kepada suasana belajar di kelas maupun di luar. Dalam pembelajaran di kelas tentunya dipengaruhi oleh interaksi guru dan peserta didik, kondisi kelas yang aktif dan menyenangkan akan membangkitkan minat peserta didik dalam belajar yang pada akhirnya dapat meningkatkan prestasi belajar peserta didik.

Kedua aspek minat (aspek kognitif dan aspek afektif) di atas sangat mempengaruhi prestasi belajar peserta didik, seperti yang diungkapkan Muhibbin Syah (1999) yang menyatakan pada dasarnya minat seseorang dapat mempengaruhi kualitas pencapaian hasil belajar peserta didik dalam bidang-bidang tertentu, karena pemusatan perhatian yang intensif terhadap materi itulah yang memungkinkan peserta didik lebih giat dan pada akhirnya mencapai prestasi yang diinginkan.

Minat yang tumbuh pada peserta didik terhadap sebuah mata pelajaran tentunya dipengaruhi oleh lingkungan baik dari materi yang disajikan atau cara penyampaian materi. Dengan demikian seorang guru selalu dituntut untuk membuat pola-pola kreatif dalam pembelajaran sehingga menimbulkan minat terhadap peserta didik untuk belajar.

Untuk mengetahui tingkat minat siswa terhadap mata pelajaran atau aktivitas, Winkel memberikan beberapa indikator yang dapat diamati (Winkel, 1989) yaitu : Perasaan senang, Perasaan tertarik, Penuh perhatian, Bersikap positif, dan Terpenuhinya kebutuhan
Pengamatan siswa dengan kelima indikator tersebut dapat mendeskripsikan tingkat minat siswa terhadap mata pelajaran atau aktivitas yang diikuti siswa.

\section{Hakikat Model Pembelajaran Role Play (Bermain Peran)}

Model pembelajaran pada dasarnya merupakan bentuk pembelajaran yang tergambar dari awal sampai akhir yang disajikan secara khas oleh guru. Dengan kata lain, model pembelajaran merupakan bungkus atau bingkai dari penerapan suatu pendekatan, strategi, model, dan teknik pembelajaran.

Berkenaan dengan model pembelajaran, Joyce and Weil (1980) mengetengahkan 4 (empat) kelompok model pembelajaran, yaitu: (1) model interaksi sosial; (2) model pengolahan informasi; (3) model personalhumanistik; dan (4) model modifikasi tingkah laku.

Model pembelajaran Role Play termasuk dalam kelompok model interaksi sosial yang menitik beratkan pada pengembangan kemampuan kerjasama dari para siswa. Model-model ini memfokuskan pada proses di mana realitas adalah negosiasi sosial. Model-model pembelajaran dalam kelompok ini memberikan prioritas pada peningkatan kemampuan individu untuk berhubungan dengan orang lain untuk meningkatkan proses demokratis dan untuk belajar dalam masyarakat secara produktif. Tokoh-tokoh teori sosial juga peduli dengan pengembangan pikiran (mind) diri sebagai pribadi dan materi keakademisan.

Model pembelajaran Role Play adalah mendramatisasikan cara bertingkah laku orangorang tertentu dalam posisi yang membedakan peranan masing-masing dalam suatu organisasi atau kelompok di masyarakat (Nawawi, 1993). Lee (1986) menyatakan bahwa "role-playing is an aspect of simulation. A whole situation is simulated in the classroom, and the participants adopt roles which belong to it". Dapat disimpulkan bahwa role-playing merupakan bagian dari kegiatan simulasi. Situasi keseluruhan disimulasikan dalam kelas, dan para pebelajarnya memerankan peran dalam situasi keseluruhan tersebut.

Menurut Harmer (2007), dalam roleplaying, peran dan bagaimana peran dilaksanakan telah dipersiapkan dan ditentukan. Ladousse (1987) menjelaskan arti dari roleplaying dengan memilah kata role play menjadi role dan play. Menurutnya, role berarti peserta 
didik memerankan bagian dalam situasi khusus. Sedangkan playing mengacu pada peran tersebut dilakukan dalam situasi tertentu dengan para peserta didik berusaha inventif dan dengan menyenangkan. Jadi secara singkat model bermain peran adalah cara atau jalan untuk mendramatisasikan cara bertingkah laku orangorang tertentu didalam posisi yang membedakan peranan masing-masing.

Apabila ditinjau secara istilah, model pembelajaran Role Play adalah bentuk model mengajar dengan mendramakan/memerankan cara bertingkah laku dalam hubungan sosial, yang lebih menekankan pada kenyataankenyataan dimana para peserta didik diikutsertakan dalam memainkan peranan di dalam mendramakan masalah-masalah hubungan sosial. Model ini kadang-kadang disebut dengan dramatisasi (Zuhairini, dkk., 1983). Dalam model ini anak diberi kesempatan untuk mengembangkan imajinasinya dalam memerankan seorang tokoh atau benda-benda tertentu dengan mendapat ulasan dari guru agar mereka menghayati sifat-sifat dari tokoh atau benda tersebut. Dalam bermain peran, anak diberi kebebasan untuk menggunakan bendabenda sekitarnya dan mengkhayalkannya jika benda tersebut diperlukan dalam memerankan tokoh yang dibawakan.

Peran penting model mengajar dalam mencapai tujuan pembelajaran adalah sangat penting. Keberhasilan sebuah mata pelajaran, terutama keberhasilan penguasaan materi pelajaran oleh peserta didik akan sangat ditentukan oleh seberapa baik seorang guru menerapkan model mengajarnya di kelas maupun di luar kelas. Model Role Play sebagai salah satu model pembelajaran yang dipilih dalam proses belajar mengajar di kelas diyakini akan mampu menjadi daya tarik tersendiri bagi peserta didik. Sebab biasanya peserta didik sangat antusias atau memperhatikan sekali terhadap pelajaran manakala pelajaran tersebut memang menyangkut kehidupannya sehari-hari di lingkungan masyarakat. Sementara model bermain peran sangat difokuskan pada kenyataan-kenyataan yang terjadi di lingkungan masyarakat. Model ini berhubungan dengan penghayatan suatu peranan sosial yang dimainkan anak di masyarakat (Nursid Sumaatmadja, 1984). Salah satu kelebihan atau keunggulan model bermain peran yaitu mampu menarik perhatian anak, sehingga suasana kelas semakin hidup (Zuhairini, dkk., 1983).

Rumusan masalah dalam penelitian tindakan ini adalah : (1) Apakah minat peserta didik dalam pembelajaran PAK dapat meningkat melalui penerapan model pembelajaran Role Play? (2) Apakah hasil belajar PAK dapat meningkat melalui penerapan model pembelajaran Role Play?

\section{METODE}

Penelitian tindakan ini akan diadakan di SMP Swasta Bethany, Jl. Kapiten Purba No. 1 Simalingkar. Penelitian ini menggunakan metode Penelitian Tindakan Kelas (Classroom Action Research). Metode ini dipilih sebagai solusi penyelesaian masalah yang berasal dari kelas dan bertujuan untuk meningkatkan kinerja. Desain penelitian yang digunakan dalam penelitian ini adalah model siklus. Model ini dikembangkan oleh Kemmis dan Mc. Taggart pada tahun 1988 dari Deakin University Australia (Asrori: 2007) .

Penelitian Tindakan Kelas (PTK) ini mengandung empat komponen utama, yaitu : perencanaan (planning), tindakan (action), pengamatan (observasi), dan refleksi (reflection).

Dalam PTK ini peneliti sebagai perancang pembelajaran berperan sebagai pelaku tindakan berkolaborasi dengan rekan guru PAK (mitra penelitian) yang bertindak sebagai kolaborator dan observer di dalam kelas. Penerapan tindakan berdasarkan permasalahan yang ada, penelitian kemungkinan pemecahan permasalahannya, implementasinya di lapangan sampai pada tahap evaluasi dan perumusan tindakan berikutnya. Penelitian ini dilakukan dalam 2 (dua) siklus dengan 4 (empat) tahapan setiap siklusnya. Perlakuan (treatment) dilakukan dalam Kompetensi Dasar (KD) 1.1. pelajaran PAK SMP Kelas IX Semester I, yaitu : memahami bentuk dan menunjukkan sikap bertanggung jawab terhadap diri sendiri pada 2 (dua) materi pokok yang telah ditentukan.

Proses penelitian tindakan ini akan dilaksanakan dalam rangkaian siklus, dan setiap siklus akan dilakukan sesuai dengan perubahan yang ingin dicapai. Lebih rinci rancangan penelitian penelitian dijabarkan sebagai berikut:

\section{Perencanaan}

\begin{tabular}{|l|l|l|}
\hline No & Tindakan & Output \\
\hline
\end{tabular}




\begin{tabular}{|l|l|l|}
\hline 1. & $\begin{array}{l}\text { Melakukan analisis instruksional } \\
\text { pada sylabus PAK dan } \\
\text { observasi awal terhadap kondisi } \\
\text { peserta didik di kelas VIII } \\
\text { semester II }\end{array}$ & $\begin{array}{l}\text { a. Sylabus PAK hasil analisis instruksional } \\
\text { b. Tingkat Minat Peserta didik } \\
\text { c. Nilai Formatif dan Submatif Peserta didik }\end{array}$ \\
\hline 2. & $\begin{array}{l}\text { Mempersiapkan materi ajar atau } \\
\text { skenario bermain peran (Role } \\
\text { Play) berdasarkan materi ajar } \\
\text { yang ditetapkan }\end{array}$ & $\begin{array}{l}\text { a. RPP } \\
\text { b. Skenario Bermain Peran }\end{array}$ \\
\hline 3. & $\begin{array}{l}\text { Membuat lembar observasi } \\
\text { untuk pengamatan proses } \\
\text { pembelajaran }\end{array}$ & $\begin{array}{l}\text { a. Lembar Observasi Keterampilan Bermain Peran } \\
\text { b. Lembar Observasi Penilaian Sikap/Penghayatan } \\
\text { c. Lembar Observasi guru }\end{array}$ \\
\hline 4. & $\begin{array}{l}\text { Membuat alat evaluasi dan } \\
\text { angket untuk mengetahui hasil } \\
\text { belajar dan peningkatan minat. }\end{array}$ & $\begin{array}{l}\text { a. Tes Formatif/Evaluasi } \\
\text { b. Angket Minat Peserta didik }\end{array}$ \\
\hline
\end{tabular}

\section{Pelaksanaan Tindakan}

Dalam tahap ini dilakukan perencanaan pembelajaran yang akan dilaksanakan dalam tahap tindakan pembelajaran.

\begin{tabular}{|c|c|c|}
\hline No. & Tindakan & Output \\
\hline \multicolumn{3}{|c|}{ SIKLUS I } \\
\hline 1. & $\begin{array}{l}\text { Fase } 1 \text { : } \\
\text { Guru melakukan brainstroming untuk melihat aspek } \\
\text { kognitif, afektif, psikomotorik, dan minat peserta didik }\end{array}$ & $\begin{array}{l}\text { Guru mendapat gambaran } \\
\text { awal (prior knowledge) } \\
\text { yang dimiliki peserta didik }\end{array}$ \\
\hline 2. & $\begin{array}{l}\text { Fase } 2 \text { : } \\
\text { Guru menjelaskan model pembelajaran bermain peran } \\
\text { (Role Play). Dalam fase ini guru menjelaskan tentang: } \\
\text { a. Materi pembelajaran } \\
\text { b. Model dan Prosedur pembelajaran } \\
\text { c. Penilaian pembelajaran } \\
\text { d. Memberikan kesempatan kepada peserta didik } \\
\quad \text { untuk bertanya mengenai materi, model, } \\
\quad \text { prosedur, dan penilaian pembelajaran } \\
\end{array}$ & $\begin{array}{l}\text { - Peserta didik memahami } \\
\text { model pembelajaran } \\
\text { bermain peran (Role Play) } \\
\text { dengan baik }\end{array}$ \\
\hline 3. & $\begin{array}{l}\text { Fase } 3 \text { : } \\
\text { Kerja Kelompok } \\
\text { a. Dalam fase ini guru membagi peserta didik dalam } \\
\text { kelompok yang terdiri dari } 5 \text { peserta didik setiap } \\
\text { kelompok. Pembagian kelompok berdasarkan } \\
\text { urutan daftar absen } \\
\text { b. Guru membagikan skenario yang telah diberikan } \\
\text { kepada kelompok } \\
\text { c. Kelompok yang telah ditentukan diberikan } \\
\text { kesempatan untuk mempelajari skenario. } \\
\text { d. Kelompok yang telah ditentukan mulai } \\
\text { mempresentasikan skenario yang telah diberikan } \\
\text { e. Setiap kelompok mendiskusikan dan menarik } \\
\text { kesimpulan dari presentasi kelompok lainnya. }\end{array}$ & $\begin{array}{l}\text { - } 3 \text { Kelompok terbentuk } \\
\text { - Kerjasama kelompok } \\
\text { mulai terjalin } \\
\text { - Presentasi bermain peran } \\
\text { terlaksana } \\
\text { - Hasil diskusi dan } \\
\text { kesimpulan dari tiap-tiap } \\
\text { kelompok tersaji }\end{array}$ \\
\hline 4. & $\begin{array}{l}\text { Fase } 4 \text { : } \\
\text { Evaluasi hasil belajar } \\
\text { Dalam fase ini guru mulai melakukan evaluasi dengan } \\
\text { memberikan tes formatif dan meminta siswa mengisi } \\
\text { angket minat }\end{array}$ & $\begin{array}{l}\text { - Skor hasil belajar dan } \\
\text { deskripsi minat peserta } \\
\text { didik didapat }\end{array}$ \\
\hline 5. & $\begin{array}{l}\text { Setelah fase } 4 \text { dilakukan, guru bersama dengan peneliti } \\
\text { melakukan evaluasi dan observasi serta refleksi hasil }\end{array}$ & $\begin{array}{l}\text { - Hasil observasi dan } \\
\text { refleksi siklus I diperoleh }\end{array}$ \\
\hline
\end{tabular}


Jurnal Teknologi Pendidikan, Vol. 11, No. 1, April 2018, p-ISSN; 1979-6692, e-ISSN: 2407-7437

\begin{tabular}{|c|c|c|}
\hline & pembelajaran siklus I & \\
\hline No. & Tindakan & Output \\
\hline \multicolumn{3}{|c|}{ SIKLUS II } \\
\hline 1. & $\begin{array}{l}\text { - Peneliti bersama kolaborator mengidentifikasi } \\
\text { masalah baru berdasarkan hasil observasi dan } \\
\text { refleksi siklus I } \\
\text { - peneliti bersama kolaborator menyusun skenario } \\
\text { pembelajaran yang sesuai dengan model pemecahan } \\
\text { masalah }\end{array}$ & $\begin{array}{l}\text { - Masalah-masalah baru dan } \\
\text { kendala yang teridentifikasi } \\
\text { - RPP/skenario pembelajaran } \\
\text { siklus } 2 \text { tersusun }\end{array}$ \\
\hline 2. & $\begin{array}{l}\text { Fase 1: } \\
\text { Penampilan drama kelompok dan diskusi kembali } \\
\text { dilakukan dengan skenario baru yang telah ditentukan }\end{array}$ & $\begin{array}{l}\text { - Hasil penampilan kelompok } \\
\text { dan diskusi diperoleh }\end{array}$ \\
\hline 4. & $\begin{array}{l}\text { Fase } 2 \text { : } \\
\text { Evaluasi hasil belajar dan peningkatan hasil. Dalam } \\
\text { fase ini guru mulai melakukan evaluasi dengan } \\
\text { memberikan tes hasil belajar dan angket minat }\end{array}$ & $\begin{array}{l}\text { - Skor hasil belajar dan } \\
\text { deskripsi minat peserta didik } \\
\text { didapat }\end{array}$ \\
\hline 5. & $\begin{array}{l}\text { Fase } 3 \text { : } \\
\text { Setelah fase } 2 \text { dilakukan, guru bersama dengan peneliti } \\
\text { melakukan evaluasi dan observasi serta refleksi hasil } \\
\text { pembelajaran siklus II }\end{array}$ & $\begin{array}{l}\text { - Hasil observasi dan refleksi } \\
\text { siklus II diperoleh }\end{array}$ \\
\hline
\end{tabular}

\section{Observasi}

Pada tahap ini dilaksanakan observasi terhadap proses pelaksanaan tindakan, efek, dan hasil. Peneliti menyiapkan alat untuk melakukan pengamatan terhadap pelaksanaan pembelajaran yang dilakukan guru, mencatat hal-hal yang mungkin terjadi selama tindakan berlangsung untuk membantu tercapainya tujuan yang direncanakan.

\section{Refleksi}

Pada tahap ini hasil yang dicapai pada tahap observasi dikumpulkan serta dianalisis. Hasil analisis direfleksikan dengan melihat data observasi, apakah proses pembelajaran yang diterapkan akan meningkatkan hasil dan minat belajar PAK peserta didik. Hasil analisis data digunakan sebagai acuan pelaksanaan siklus selanjutnya dan menentukan indikator pencapaian.

\section{Teknik Pengumpulan Data dan Instrumen Penelitian}

Pada penelitian tindakan ini pengumpulan data dilakukan dengan pengamatan atau observasi melalui pencatatan terhadap aktivitas atau perilaku peserta didik untuk menjaring penghayatan, sikap, dan minat peserta didik melalui pembelajaran bermain peran (Role Play), serta tes hasil belajar.
Instrumen pengumpulan data yang digunakan dalam penelitian ini terdiri atas dua instrument, yaitu : Lembar Observasi, Lembar Tes

Tujuan dari instrument tersebut adalah : (1) untuk menjaring penghayatan, sikap, dan minat peserta didik (2) uji kompetensi tiap topik (tes formatif) dan (3) pengamatan perilaku peserta didik.

\section{Instrumen Penelitian :}

1. Lembar Observasi Keterampilan Bermain Peran (Penilaian Psikomotorik)

Lembar Pengamatan Bermain Peran disusun untuk mengetahui tingkat keberhasilan pelaksanaan keterampilan bermain peran dan dipakai sebagai aspek untuk mengukur peningkatan minat peserta didik. Instrumen ini berisi tentang kegiatan yang dilakukan oleh peserta didik, dengan 6 indikator yang disusun berdasarkan langkah-langkah model bermain peran menurut (Shaftel, 1967).

2. Lembar Observasi Pengamatan Sikap/Penghayatan (Penilaian Afektif) Instrumen Pengamatan Sikap (Penilaian Afektif) berisi tentang sikap dan perilaku yang ditunjukkan oleh peserta didik selama proses pembelajaran berlangsung, dengan 10 indikator penilaian atau pengamatan.

3. Tes Hasil Belajar

Tes hasil belajar yang digunakan dalam penelitian ini berbentuk tes tulis uraian/esai 
dan skala sikap atau lembar penilaian diri yang disusun sesuai dengan indikator pencapaian setiap materi ajar.

\section{Teknik Analisis Data}

Analis data merupakan tahapan yang dilakukan setelah pengumpulan data. Dalam penelitian ini data yang dianalisis adalah data kualitatif yang berkaitan dengan peningkatan minat dan hasil belajar yang diperoleh selama dan sesudah proses pembelajaran dengan menggunakan model bermain peran (Role Play) dilakukan.

Teknik analisis data secara kualitatif merujuk kepada Miles and Huberman (1992) sebagai berikut : (1) reduksi data, dalam hal ini peneliti memiliki data yang relevan, penting dan yang berguna untuk menjelaskan tentang apa yang menjadi sasaran analisis, (2) sajian deskriptif tentang apa yang ditemukan dalam analisis, yang disajikan dalam bentuk narasi dan gambaran visual dan (3) verifikasi atau penarikan kesimpulan. Verifikasi dapat dilakukan dengan cara : Credibility, Transferability, Dependability, dan Confirmability

Teknik pemeriksaan data lainnya yang digunakan dalam penelitian ini adalah audit trail, hal ini dimaksudkan agar seluruh proses penelitian yang dilaksanakan dapat tepat dan akurat. Audit artinya pemeriksaan terhadap ketelitian penelitian yang dilakukan sehingga timbul keyakinan bahwa apa yang dilaporkan itu apa adanya, sedangkan trail artinya jejak yang dapat dilacak dan ditelusuri.

Observasi terhadap aktivitas peserta didik dalam pembelajaran bermain peran dilakukan selama pembelajaran berlangsung selang 40 menit. Hasil observasi dianalisis dengan jumlah skor yang diperoleh dibagi jumlah skor maksimal dikali $100 \%$.

1. Analisis Lembar Observasi Keterampilan Bermain Peran

Skala penilaian yang digunakan dalam instument ini adalah :skor 1 = tidak baik; skor 2 = kurang baik; skor $3=$ cukup; 4 = baik; skor 5 = sangat baik. Skala disusun berdasarkan skala semantic differensial yang dikembangkan oleh Osgood, dkk.

Untuk mengetahui seberapa besar tingkat keberhasilan pelaksanaan ketrampilan bermain peran dan peningkatan minat, digunakan kualifikasi sebagai berikut:

\begin{tabular}{|c|c|c|}
\hline No & Prosentase & Kualifikasi \\
\hline 1 & $<60$ & Tidak baik \\
\hline
\end{tabular}

\begin{tabular}{|c|c|c|}
\hline 2 & $60-69$ & Kurang baik \\
\hline 3 & $70-79$ & Cukup \\
\hline 4 & $80-89$ & Baik \\
\hline 5 & $90-100$ & Sangat baik \\
\hline
\end{tabular}

2. Analisis

Lembar

Observasi

Sikap/Penghayatan

Skala penilaian yang digunakan untuk observasi pengamatan sikap adalah : skor $1=$ tidak baik; skor $2=$ kurang baik; skor $3=$ cukup; skor $4=$ baik; skor $5=$ sangat baik. Skala disusun berdasarkan skala semantic differensial yang dikembangkan oleh Osgood,dkk.

Untuk mengetahui skala sikap dalam pelaksanaan ketrampilan kerja sama peserta didik dalam kelompok, digunakan kualifikasi sebagai berikut :

\begin{tabular}{|l|c|c|}
\hline No & Prosentase & Kualifikasi \\
\hline 1 & $<60$ & Tidak baik \\
\hline 2 & $60-69$ & Kurang baik \\
\hline 3 & $70-79$ & Cukup \\
\hline 4 & $80-89$ & Baik \\
\hline 5 & $90-100$ & Sangat baik \\
\hline
\end{tabular}

\section{Angket Minat}

Skala penilaian yang digunakan untuk observasi pengamatan sikap adalah : skor $3=$ Setuju; skor 2 = Netral; skor $1=$ Tidak Setuju. Skala penilaian disusun berdasarkan skala linkert dengan 3 tingkatan.

Untuk mengetahui skala tingkat minat terhadap mata pelajaran PAK, digunakan kualifikasi sebagai berikut:

\begin{tabular}{|c|c|c|}
\hline No & Prosentase & Kualifikasi \\
\hline 1 & $<60$ & Tidak Berminat \\
\hline 2 & $60-69$ & Kurang Berminat \\
\hline 3 & $70-79$ & Cukup Berminat \\
\hline 3 & $80-89$ & Berminat \\
\hline 4 & $90-100$ & Sangat Berminat \\
\hline
\end{tabular}

\section{Analisis Observasi Proses Pembelajaran Guru}

Skala penilaian yang digunakan untuk observasi pengamatan sikap adalah : skor $1=$ tidak baik; skor $2=$ kurang baik; skor $3=$ cukup; skor $4=$ baik; skor $5=$ sangat baik.

Untuk mengetahui tingkat keberhasilan guru dalam melaksanakan pembelajaran dengan model role play, digunakan kualifikasi sebagai berikut:

\begin{tabular}{|c|c|c|}
\hline No & Prosentase & Kualifikasi \\
\hline 1 & $<60$ & Tidak baik \\
\hline
\end{tabular}




\begin{tabular}{|c|c|c|}
\hline 2 & $60-69$ & Kurang baik \\
\hline 3 & $70-79$ & Cukup \\
\hline 4 & $80-89$ & Baik \\
\hline 5 & $90-100$ & Sangat baik \\
\hline
\end{tabular}

5. Analisis Tes Hasil Belajar

Analisis data yang digunakan dalam menilai hasil belajar dan ketuntasan belajar adalah sebagai berikut :

Secara individual, peserta didik telah tuntas belajar jika mencapai skor $75 \%$ atau nilai 75 dengan berdasarkan nilai Kriteria Ketuntasan Minimal (KKM) yang ditetapkan sekolah :

$$
\text { SkorSiswa }=\frac{\text { Skor yang diperoleh }}{\text { Skormaksimum }} \times 100 \%
$$

Suatu kelas dinyatakan tuntas belajar jika terdapat $\geq 80 \%$ dari jumlah peserta didik telah tuntas belajar. Perhitungan untuk menyatakan ketuntasan belajar peserta didik secara klasikal :

$$
\frac{\text { jumlah siswa yang tuntas }}{\text { jumlah siswa seluruhnya }} \times 100 \%
$$

\section{Indikator Keberhasilan}

Indikator keberhasilan penelitian ini adalah adanya peningkatan minat dan hasil belajar PAK yang ditandai dengan ciri-ciri antara lain : para peserta didik menunjukkan sikap antusiasnya dan senang dalam mengikuti pelajaran PAK, terlibat aktif dalam interaksi pembelajaran sehingga peserta didik termotivasi dan mampu menuliskan atau menuangkan apa yang telah dipelajarinya.

Tindakan penelitian ini akan dihentikan apabila $80 \%$ peserta didik telah mampu mendapatkan nilai $\geq 75$ (KKM) dan $80 \%$ peserta didik telah menunjukkan minat yang baik terhadap pelajaran PAK.

\section{HASIL PENELITIAN}

Analisis deskriptif peningkatan minat dan hasil belajar pada pelaksanaan tindakan di siklus I dan II tergambar pada tabel-tabel berikut :

Tabel 1. Analisis Peningkatan Minat Siklus I \& II

\begin{tabular}{|l|l|c|c|c|c|c|}
\hline \multirow{2}{*}{ No. } & \multirow{2}{*}{ Kategori } & \multicolumn{2}{|c|}{ Frekuensi } & \multicolumn{2}{c|}{ Prosentase } & \multirow{2}{*}{ Peningkatan } \\
\cline { 3 - 6 } & & $\begin{array}{c}\text { Siklus } \\
\text { I }\end{array}$ & $\begin{array}{c}\text { Siklus } \\
\text { II }\end{array}$ & $\begin{array}{c}\text { Siklus } \\
\text { I }\end{array}$ & $\begin{array}{c}\text { Siklus } \\
\text { II }\end{array}$ & \\
\hline 1. & Tidak Berminat & 0 & 0 & $0 \%$ & $0 \%$ & $0 \%$ \\
\hline 2. & Kurang Berminat & 1 & 1 & $6.66 \%$ & $6.66 \%$ & $0 \%$ \\
\hline 3. & Cukup Berminat & 6 & 2 & $40 \%$ & $13.33 \%$ & $26.67 \%$ \\
\hline 4. & Berminat & 7 & 7 & $\mathbf{4 6 . 6 6 \%}$ & $\mathbf{4 6 . 6 6 \%}$ & $0 \%$ \\
\hline 5. & Sangat Berminat & 1 & 5 & $\mathbf{6 . 6 6} \%$ & $\mathbf{3 3 . 3 3 \%}$ & $26.67 \%$ \\
\hline & Jumlah & 15 & 15 & $100 \%$ & $100 \%$ & $53.3 \%$ \\
\hline
\end{tabular}

Dari tabel tersebut terlihat bahwa, di siklus I terdapat 8 dari 15 siswa atau $53.3 \%$ siswa yang telah menunjukkan berminat yang baik dan sangat baik terhadap pelajaran PAK. Sedangkan di siklus II terdapat 12 dari 15 siswa atau $80 \%$ siswa yang telah menunjukkan minat yang baik dan sangat baik terdapat pelajaran PAK.

Tabel 2. Analisis Peningkatan Hasil Belajar (Formatif) Siklus I \& II

\begin{tabular}{|l|c|c|c|c|c|}
\hline \multirow{2}{*}{ No. } & \multirow{2}{*}{ Kategori } & \multicolumn{2}{|c|}{ Frekuensi } & \multicolumn{2}{c|}{ Prosentase } \\
\cline { 2 - 5 } & Siklus I & Siklus II & Siklus I & Siklus II \\
\hline 1. & Sangat Rendah $(<60)$ & 1 & 0 & $6,66 \%$ & $0 \%$ \\
\hline 2. & Rendah $(60-69)$ & 4 & 0 & $26,66 \%$ & $0 \%$ \\
\hline 3. & Cukup $(70-79)$ & 6 & 4 & $40 \%$ & $26,66 \%$ \\
\hline & $<75$ & $(2)$ & $(3)$ & $(13,33 \%)$ & $(20 \%)$ \\
& $K K M(75)$ & $(4)$ & $(1)$ & $(26,66 \%)$ & $(6,66 \%)$ \\
\hline 4. & Baik $(80-89)$ & 4 & 7 & $26,66 \%$ & $46,66 \%$ \\
\hline 5. & Sangat Baik ( $\geq 90)$ & - & 4 & $0 \%$ & $26,66 \%$ \\
\hline
\end{tabular}




\begin{tabular}{|l|l|l|l|l|l|}
\hline & Jumlah & 15 & 15 & $100 \%$ & $100 \%$ \\
\hline
\end{tabular}

Dari tabel tersebut terlihat bahwa di siklus I 8 dari 15 siswa atau $53 \%$ telah mencapai nilai diatas KKM, terjadi peningkatan $13.3 \%$ dari kondisi awal sebelum dilakukan tindakan. Data di siklus II menunjukkan 12 dari 15 siswa atau $80 \%$ telah mencapai nilai di atas KKM atau meningkat $40 \%$ dari kondisi awal sebelum tindakan. Pada siklus II ini telah diperoleh tujuan yang diharapkan yaitu : (1) 80 $\%$ siswa telah menunjukkan minat yang baik terhadap pelajaran PAK, dan (2) $80 \%$ telah mencapai nilai di atas KKM.

Peningkatan minat dan hasil belajar siklus I dan II dapat dilihat pada diagram berikut :

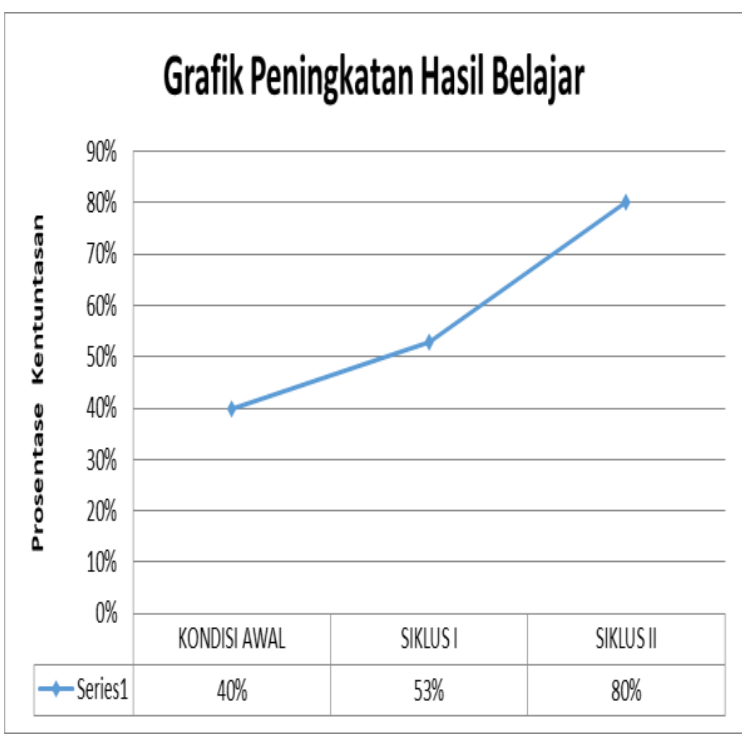

Gambar 1. Grafik Peningkatan Hasil Belajar

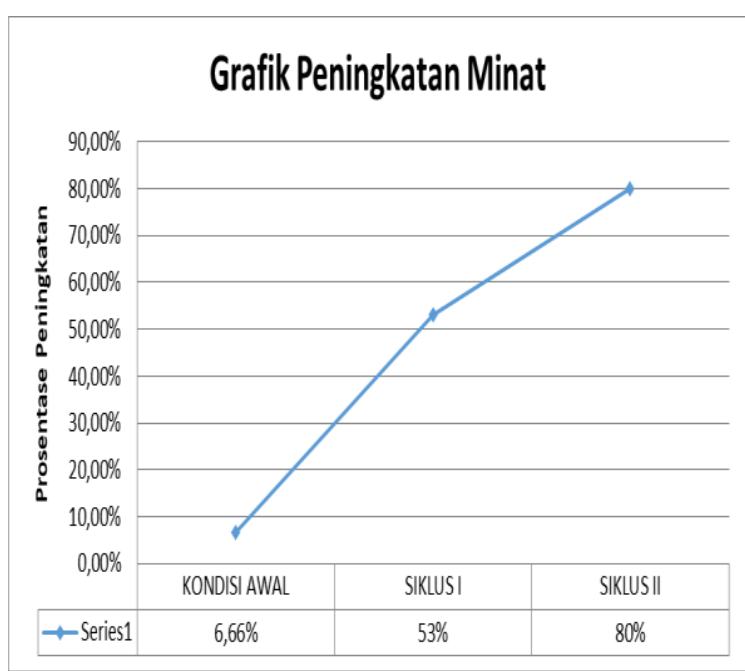

Gambar 2. Grafik Peningkatan Minat
Hasil temuan yang menarik dari pelaksanaan tindakan siklus I dan II adalah bahwa peningkatan hasil belajar sejalan (equal) dengan peningkatan minat. Hal tersebut tergambar pada diagram batang berikut :

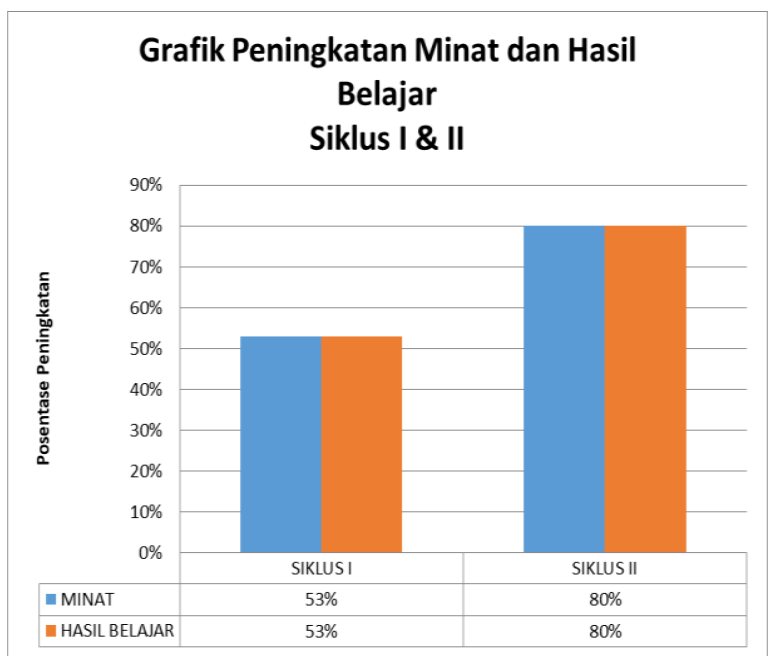

Gambar 3. Grafik Peningkatan Minat dan Hasil Belajar

\section{PEMBAHASAN}

Pada dasarnya penelitian tindakan kelas ini bertujuan untuk memperoleh gambaran peningkatan minat siswa terhadap pelajaran PAK dan peningkatan hasil belajar PAK melalui penerapan model Role Play. Dalam bagian ini akan dipaparkan hasil temuan dalam peneliti yang dideskripsikan dan dianalisis oleh peneliti dibantu oleh kolaborator.

Keberhasilan atau kesuksesan dalam sebuah penelitian ditentukan oleh dua faktor yang saling terkait dan tidak dapat dipisahkan yaitu, peneliti dan subyek penelitian. Dalam penelitian ini guru pengajar memiliki peran ganda, yang pertama berperan sebagai pengajar dan yang kedua berperan sebagai peneliti, sehingga guru bertanggungjawab penuh terhadap proses penelitian mulai dari tahap persiapan, pelaksanaan penelitian sampai pada akhirnya melakukan pengevaluasian hasil penelitian. Peneliti yang bertindak sebagai guru yang melaksanakan pembelajaran memiliki peranan yang penting dalam menyajikan materi dan mengarahkan subyek penelitian.

Dalam melaksanakan tindakan di siklus I dan II, guru pengajar yang juga bertindak sebagai peneliti tidak menemukan kendala-kendala yang sangat berarti dalam melaksanakan, membimbing, dan mengevaluasi 
proses pembelajaran dengan penerapan model Role Play. Hal ini dikuatkan oleh hasil observasi kegiatan oleh kolaborator yang juga merupakan pengajar PAK sekaligus kepala sekolah ditempat penelitian berlangsung. Hasil observasi guru menunjukkan bahwa guru mampu menjalankan atau melaksanakan aspekaspek yang terdapat dalam format observasi dalam pengelolaan pembelajaran dengan penerapan model Role Play, atau dengan kata lain guru telah memenuhi keriteria indikator keberhasilan tindakan yang terdapat dalam penelitian ini.

Kualitas kegiatan pembelajaran melalui penerapan model Role Play berjalan dengan baik dengan indikator rata-rata tingkat ketrampilan bermain peran (penilaian psikomotorik) dan penghayatan/sikap siswa (penilaian afektif) berada pada kategori baik di siklus I dan meningkat menjadi sangat baik di siklus II.

Hipotesis I yang menyatakan bahwa penerapan model pembelajaran Role Play akan meningkatkan minat siswa terhadap pelajaran PAK terbukti dengan peningkatan minat siswa di kedua siklus. Di siklus I, terdapat $53 \%$ siswa atau 8 dari 15 siswa telah menunjukkan minat yang baik (7 siswa) dan sangat baik (1 siswa). Peningkatan tersebut meningkat di siklus II menjadi $80 \%$ siswa atau 12 dari 15 siswa telah menunjukkan minat yang baik (7 siswa) dan sangat baik (5 siswa) terhadap pelajaran PAK.

Peningkatan minat yang terjadi di kedua siklus tersebut sejalan dengan peningkatan hasil belajar. Di siklus I, terdapat $53 \%$ siswa atau 8 dari 15 siswa yang telah mencapai nilai di atas KKM. Di siklus II, hasil belajar meningkat menjadi $80 \%$ atau 12 dari 15 siswa telah mencapai nilai di atas KKM. Berdasarkan temuan tersebut hipotesis II yang menyatakan bahwa peningkatan hasil belajar PAK akan meningkat melalui penerapan model pembelajaran Role Play juga terbukti.

Peningkatan minat dan hasil belajar yang sejalan tersebut memperkuat pendapat para ahli yang terdapat di kajian teori yang menyatakan bahwa minat seseroang dapat mempengaruhi kualitas pencapaian hasil belajar siswa dalam bidang-bidang tertentu karena pemusatan yang intensif terhadap materi itulah yang memungkinkan siswa lebih giat dan pada akhirnya mencapai prestasi yang diinginkan.
Berdasarkan hal-hal tersebut, yaitu : (1) guru telah memainkan peran dengan baik dalam menerapkan model Role Play dalam pembelajaran, (2) tingkat ketrampilan bermain peran dan tingkat penghayatan/sikap berada pada kategori sangat baik, (3) telah terjadi peningkatan minat dan hasil belajar yang ditetapkan, maka penelitian ini dapat dinilai sudah berhasil.

\section{PENUTUP}

Pertama, penerapan model Role Play pada pembelajaran PAK dapat meningkatkan minat siswa pada pelajaran tersebut. Peningkatan minat terlihat pada dua siklus tindakan. Hasil tindakan siklus I menunjukkan $53 \%$ siswa telah menunjukkan minatnya terhadap pelajaran PAK, dan di siklus II minat siswa terhadap pelajaran PAK meningkat menjadi $80 \%$.

Kedua, penerapan model Role Play pada pembelajaran PAK dapat meningkatkan hasil belajar PAK. Yang menarik dari hasil penelitian ini adalah bahwa peningkatan hasil belajar sejalan atau sebanding dengan peningkatan minat siswa. Di siklus I, $53 \%$ siswa atau 8 dari 15 siswa telah mencapai nilai kriteria ketuntasan minimal $(\geq 75)$ dengan nilai tertinggi siswa 85 . Peningkatan hasil belajar terjadi di siklus II dimana $80 \%$ siswa atau 12 dari 15 siswa telah mencapai nilai kriteria ketuntasan minimal $(\geq 75)$ dengan nilai tertinggi siswa 96.

\section{DAFTAR PUSTAKA}

Barnes, D. (1977). From Communication to Curriculum. New York : Madison Avenue.

Hurlock. E. B. (1993). Psikologi Perkembangan . Edisi ke-5. Jakarta : Erlangga.

Joyce, B. (1980). Models of Teaching. New Jersey : Prentice Hall

Muhibbin, S. (2003). Psikologi Belajar. Jakarta : PT Raja Grafindo.

Slameto. (2003). Belajar dan Faktor-Faktor yang Mempengaruhinya. Jakarta : Rineka Cipta

Winkel. (1983). Psikologi Pendidikan dan Evaluasi Belajar. Jakarta : Gramedia 